\title{
Autumn sowing and first-year mowing enhance flowering species abundance and diversity in wildflower strips
}

\author{
Julien Piqueray ${ }^{(1)}$, Valentin Gilliaux ${ }^{(1)}$, Bernard Bodson ${ }^{(2)}$, Grégory Mahy ${ }^{(3)}$ \\ (1) Natagriwal ASBL.Passage des Déportés, 2.BE-5030 Gembloux (Belgium).E-mail: jpiqueray@ natagriwal.be \\ (2) University of Liège - Gembloux Agro-Bio Tech. TERRA Teaching and Research Centre, Crop Science. Passage des \\ Déportés, 2. BE-5030 Gembloux (Belgium). \\ (3) University of Liège - Gembloux Agro-Bio Tech. Biodiversity and Landscape. Passage des Déportés, 2. BE-5030 \\ Gembloux (Belgium).
}

Received 13 December 2019, accepted 18 November 2020, available online 1 December 2020.

This article is distributed under the terms and conditions of the CC-BY License (http://creativecommons.org/licenses/by/4.0)

Description of the subject. Wildflower strips are used to provide flower resources for insects in agroecosystems. There is a need to determine implementation processes that maximize the development of the sown flowering species.

Objectives. To determine the effect of i) sowing period (autumn and spring) and ii) early cutting of annuals during the first growing season on the development of the sown perennial species.

Method. We surveyed species development during three years (2012-2014) in 24 plots in an experimental wildflower strip. Plots were sown either in autumn or in spring, and received or not an early cutting management in 2012.

Results. Sown species were favored by autumn sowing. A few species did better after spring sowing. Two years later (2014), early cutting management enhanced sown flowering species abundance and diversity in case of spring sowing only.

Conclusions. Studying implementation and management protocols is of first importance to improve the efficiency of wildflower strips. We recommend autumn sowing as a first approach, and mowing aimed at controlling annuals in the first year after sowing.

Keywords. Agri-environmental scheme, wildflower strip, sowing date, vegetation cutting, first year management, Belgium.

La période de semis et la gestion en première année influent sur l'abondance et la diversité des fleurs dans les bandes fleuries

Description du sujet. Les bandes fleuries sont utilisées pour fournir des ressources florales aux insectes des agro-écosystèmes. Il est nécessaire de déterminer les processus de mise en œuvre qui optimisent le développement des fleurs semées.

Objectifs. Déterminer l'effet de i) la période d'ensemencement (automne et printemps) et ii) la coupe précoce des annuelles pendant la première saison de végétation, sur le développement des espèces pérennes semées.

Méthode. Nous avons étudié le développement des espèces pendant trois ans (2012-2014) dans 24 parcelles situées dans une bande fleurie expérimentale. Les parcelles ont été semées à l'automne ou au printemps et ont bénéficié ou non d'une gestion par coupe précoce en 2012.

Résultats. Les espèces semées ont été favorisées par le semis d'automne. Quelques espèces ont préféré le semis de printemps. Deux ans plus tard (2014), la gestion par coupe précoce a amélioré l'abondance et la diversité des fleurs semées en cas de semis de printemps.

Conclusions. L'étude des protocoles de mise en œuvre et de gestion est primordiale pour améliorer l'efficacité des bandes fleuries. Nous recommandons le semis d'automne comme première approche et le contrôle des annuelles par fauche la première année après le semis.

Mots-clés. Mesures agro-environnementales, bande fleurie, date de semis, coupe de la végétation, gestion en première année, Belgique. 


\section{INTRODUCTION}

Recently, strong biodiversity declines have been observed in agricultural landscapes due to their intensification (Stoate et al., 2001). Wildflower strip implementation in arable fields was therefore encouraged through agri-environmental subsidies with the aim to support flower-feeding insect populations as well as insect-mediated ecosystem services (Batáry et al., 2015; Uyttenbroeck et al., 2016).

Implementing strips that provide flowers over the long term has proven to be challenging (Smith et al., 2010; Westbury et al., 2017). One response is to recreate mown grasslands using perennial indigenous forbs and grasses (Kirmer et al., 2018; Piqueray et al., 2019). However, discrepancies may occur between what is sown and what is actually obtained in the field (Uyttenbroeck et al., 2017; Schmidt et al., 2020). There is therefore a need to determine implementation processes that maximize the development of the sown species.

First, the sowing period may influence the emergence of sown species. Indeed, many grassland species have a seasonal seedling emergence pattern that drives their response to management practices (Piqueray et al., 2015). Second, weeds germinating from the seed bank may interfere with seedling emergence of the sown species. Annual weeds may be too strong competitors in the first year for slow-growing perennials. Early cutting of these annuals, aimed at reducing their competitive power, has been shown to improve establishment success in perennial grasslands (Meissen et al., 2020). We therefore propose to apply this technique in the case of wildflower strips as well.
We hypothesize that:

- different sowing periods (autumn and spring) will favor different species from the seed mix;

- early cutting of annuals during the first growing season will enhance the development of the sown perennial species.

\section{MATERIALS AND METHODS}

\subsection{Experimental design}

An experimental strip ( $24 \mathrm{~m} \times 120 \mathrm{~m})$ was sown in Gembloux, Belgium (50³0'53”N-443'52.9”E; alt. $170 \mathrm{~m}$; annual mean temperature ca. $9^{\circ} \mathrm{C}$, annual rainfall ca. $800 \mathrm{~mm}$ evenly distributed along the year) (Figure 1). Soil at the site is very fertile (World Reference Base soil group: retisol). Flowering species included in the seed mix are listed in Appendix 1. Sowing density was $30 \mathrm{~kg} \cdot \mathrm{ha}^{-1}$. Seeds were sown at the ground surface. Grasses (Festuca rubra L., Poa pratensis L. and Agrostis stolonifera L.) accounted for $85 \%$ of the seed mix mass, legumes for $4 \%$ and other flowering species for $11 \%$ (see Piqueray et al., 2019 for more details). Half of the strip (24 m x $60 \mathrm{~m}$ ) was sown in autumn, on $23^{\text {rd }}$ September 2011, the other half was sown in spring, on $14^{\text {th }}$ May 2012. In each half, 12 experimental plots $(7.5 \mathrm{~m} \times 7.5 \mathrm{~m})$ were installed at regular distances (Figure 1). An early cutting management was applied in 6 of the 12 plots during the first vegetation year. This consisted in cutting the vegetation at a $20-\mathrm{cm}$ height before the annual species produced seeds. This happened on $21^{\text {st }}$ June 2012 for the autumn sowing zone and on $26^{\text {th }}$ July 2012 for the

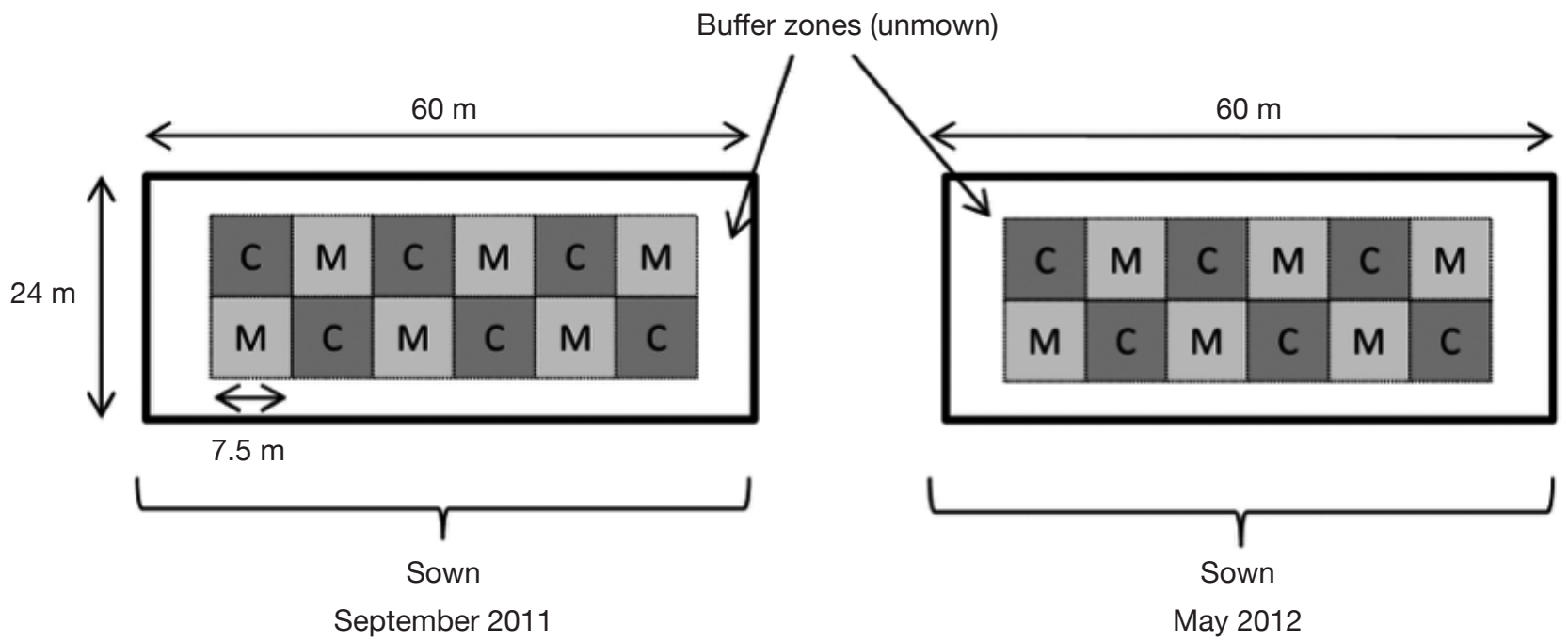

Figure 1. Schematic representation of the field experiment - Représentation schématique du dispositif expérimental. M: early mowing - fauchage précoce; C: control - témoin. 
spring sowing zone. Thereafter, mowing occurred each year at the end of August in all plots.

A vegetation survey was done each year in late June. All vascular plant species were recorded, as well as their cover in \%. The survey was done in $5 \mathrm{~m}^{2}$ $(2.25 \mathrm{~m} \times 2.25 \mathrm{~m})$ quadrats placed at the center of each experimental plot. In 2012, only the plots without early mowing management were surveyed (12 plots). In 2013 and 2014 , all the 24 plots were surveyed.

\subsection{Data analysis}

In order to illustrate vegetation contrasts between years, sowing periods (autumn and spring) and occurrence of an early cutting management, we performed a Principal Coordinate Analysis (PCoA) based on the Bray-Curtis distance matrix among quadrats.

Using one-way ANOVAs, we tested the effect of early mowing management on:

- the cover of sown perennial flowering species;

- Shannon diversity of sown perennial flowering species (log-transformed);

- the cover of sown annual species (log-transformed);

- the cover of perennial weeds (log-transformed);

- the cover of annual weeds (sqrt-transformed).

The effect of sowing period was not considered in statistical analyses, as plots were not spatially independent.

Nomenclature follows Lambinon et al. (2004). Analyses were conducted in R 3.5.1, including the package 'vegan' (Oksanen et al., 2016; R Core Team, 2018).

\section{RESULTS}

The PCoA revealed that, in 2012, annuals from the seed mix (Centaurea cyanus L., Papaver rhoeas L.) dominated the autumn-sown zone (Figure 2). In the spring-sown zone, spontaneous annuals were the most abundant (Table 1), notably Sonchus asper (L.) Hill. In 2013 and 2014, the sown perennial species Malva moschata L. and Silene latifolia ssp. alba (Mill.) Greuter $\&$ Burdet were more abundant in the spring-sown zone. The cover of most of the sown perennial species (e.g. Centaurea jacea L., Lotus corniculatus L.), was higher with autumn sowing (Figure 2). The occurrence of these species in spring-sown plots was favored by early mowing in 2012 . This resulted in a higher diversity for sown perennials in $2013(p=0.009)$ and $2014(p<0.001)$ in spring-sown plots that had an early cutting management. Also, the cover of sown perennials in these plots significantly increased in 2014 (Table 1) and reached $42.0 \%$, very close to the $42.4 \%$ obtained for autumn-sown plots without early cutting (Table 1).

\section{DISCUSSION}

Spring and autumn sowing resulted in different vegetation trajectories. This may partly be explained by the germination phenology of some species. For instance, S. latifolia ssp. alba has its seedling emergence peak in April (Roberts \& Boddrell, 1984), which is congruent with its relation to spring sowing. Sowing date resulted in different annual species compositions in 2012. In the spring sown zone, the weeds S.asper and Chenopodium album L. were dominant. These species are both summer annuals (Milberg \& Andersson, 1998) that have a rapid development following their emergence. Such species are likely to be more competitive compared to the slowgrowing perennials included in the seed mix. This may also explain that early mowing, through the destruction of these strong competitors, had a stronger effect in the case of spring sowing. This result is congruent with Meissen et al. (2020), who found that first-year mowing may accelerate the reconstruction of perennial herbaceous ecosystems. Silene latifolia ssp. alba and M. moschata may perform better in competition with spring annuals due to their ruderal habit, including rapid growing abilities (Roberts \& Boddrell, 1984).

These results should however be considered as preliminary. The experiment was indeed conducted in a single site and on a single year. Moreover, sowing date was not randomized in the experimental protocol, making impossible a statistical validation of the observed pattern. However, we are rather confident with our results because it was congruent with what was expected from the previous studies, notably concerning the emergence seasonality of the species. Also, the protocol that includes autumn sowing was made mandatory in wildflower strips from 2016 in Wallonia (South Belgium). Since then, reports from farm advisors of failures in implementing wildflower strips became scarce. We therefore think this study provides valid recommendations for the implementation of wildflower strips using our seed mix, including the autumn sowing period.

\section{CONCLUSIONS}

Many authors have stressed the fact that species composition is an important issue for the efficacy of wildflower strips at preserving insects and insectmediated ecosystem services (Hatt et al., 2017; Nichols et al., 2019). However, sowing a given seed mix is definitely not sufficient to obtain the nominal flowering species composition displayed on the seed mix package (Uyttenbroeck et al., 2015). Our study demonstrated that the implementation protocol of wildflower strips in the first year has an effect on abundance and diversity 


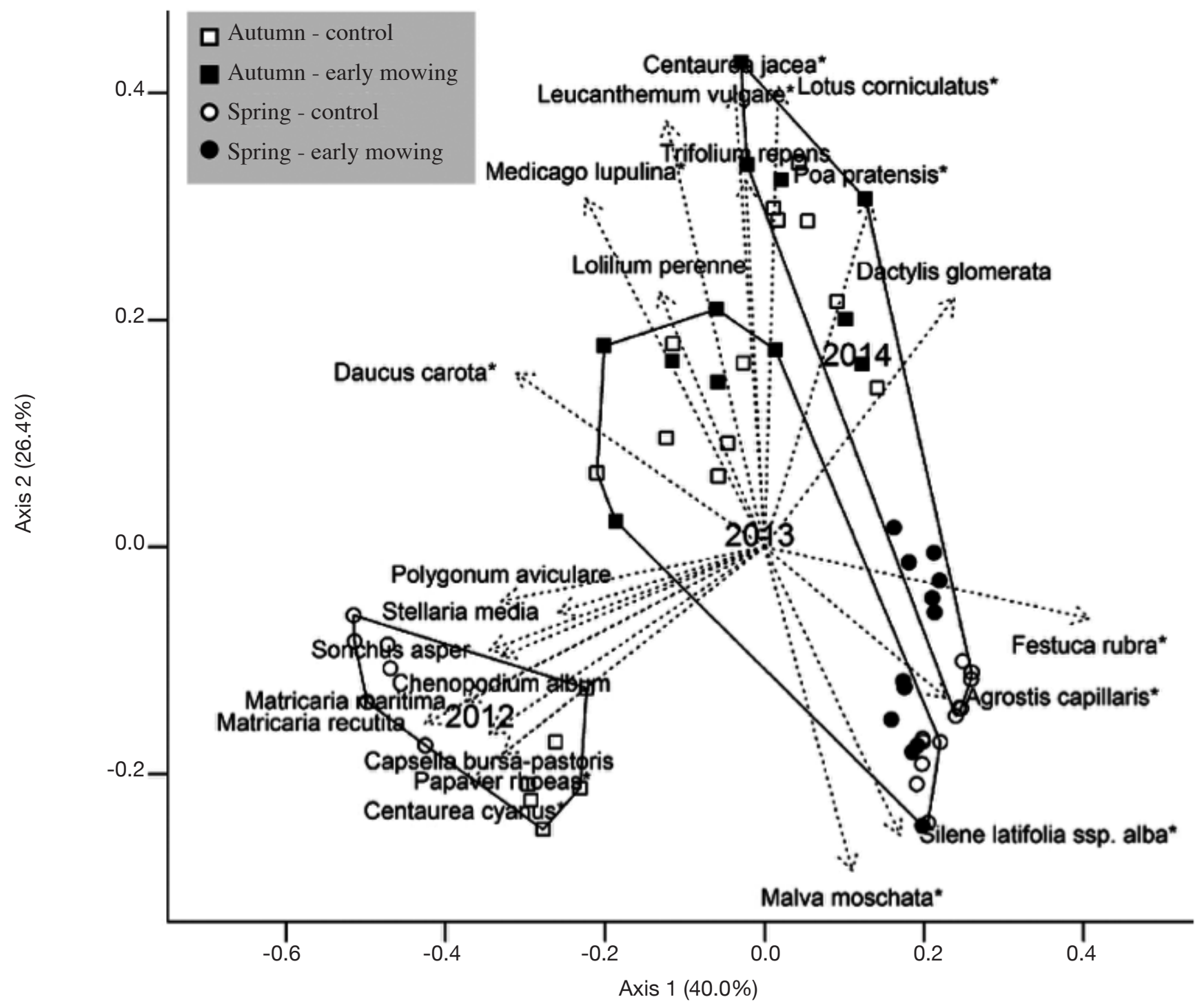

Figure 2. Principal coordinate analysis of the experimental plots - PCoA des parcelles expérimentales.

Plots of the same year are contained within convex hulls. Arrows are the projection of species in the PCoA plane (only species with correlation $>0.5$ are shown). The length of the arrows indicates the degree to which an increase in cover by the plant species is correlated with one or both axes. Species marked with an * were included in the seed mix - Les parcelles relevées la même année sont incluses dans des polygones de Hull. Les flèches sont les projections des espèces dans le plan de la PCoA (seules les espèces avec une corrélation > 0,5 ont été affichées). La longueur des flèches indique une tendance à l'augmentation du recouvrement par l'espèce. Les espèces marquées d'une * étaient incluses dans le mélange de graines semé.

in the following years. We therefore argue that studying implementation and management protocols is of prime importance to improve the efficiency of such agri-environment schemes. Especially, we recommend paying special attention to the emergence seasonality of the species included in seed mixes in order to adapt the sowing period. Most of the species found in our seed mix were enhanced by autumn sowing, which we recommend therefore to favor as a first approach. This should however be confirmed through a multi-year and multi-site randomized experiment. Our study also demonstrated that managing annual weeds in the first year after sowing can be crucial in providing the best growing conditions for flowering species from the seed mix, especially in case of spring sowing as weedy spring annuals are strong competitors.

\section{Acknowledgements}

The authors acknowledge Dirk Verhulst for the implantation and management of the experiment. Natagriwal is a non-forprofit association funded by the Walloon government. 
Wildflower strips implementation

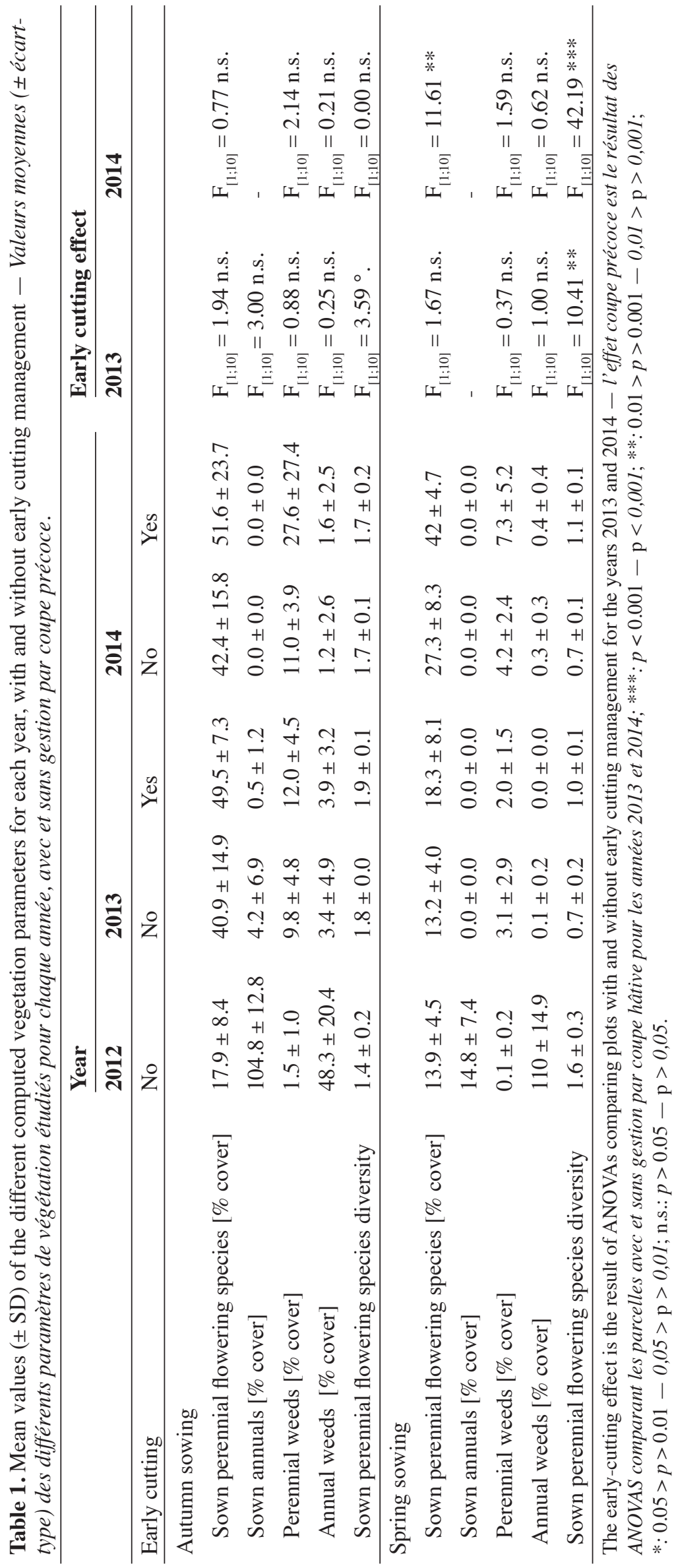




\section{Bibliography}

Batáry P., Dicks L.V., Kleijn D. \& Sutherland W.J., 2015. The role of agri-environment schemes in conservation and environmental management. Conserv. Biol., 29(4), 1006-1016, doi.org/10.1111/cobi.12536

Hatt S. et al., 2017. Do flower mixtures with high functional diversity enhance aphid predators in wildflower strips? Eur. J. Entomol., 114, 66-76, doi.org/10.14411/ eje. 2017.010

Kirmer A., Rydgren K. \& Tischew S., 2018. Smart management is key for successful diversification of field margins in highly productive farmland. Agric. Ecosyst. Environ., 251, 88-98, doi.org/10.1016/j. agee.2017.09.028

Lambinon J., Delvosalle L. \& Duvigneaud J., 2004. Nouvelle flore de Belgique, du Grand-Duché de Luxembourg, du Nord de la France et des régions voisines. Meise, Belgique : Jardin botanique national de Belgique.

Meissen J.C. et al., 2020. Seed mix design and first year management influence multifunctionality and costeffectiveness in prairie reconstruction. Restor. Ecol., 28(4), 807-816, doi.org/10.1111/rec.13013

Milberg P. \& Andersson L., 1998. Does cold stratification level out differences in seed germinability between populations? Plant Ecol., 134, 225-234, doi. org/10.1023/A:1009793119466

Nichols R.N., Goulson D. \& Holland J.M., 2019. The best wildflowers for wild bees. J. Insect Conserv., 23(5-6), 819-830, doi.org/10.1007/s10841-019-00180-8

Oksanen A.J. et al., 2016. The $R$ package 'vegan '(Version 2.4-0).

Piqueray J. et al., 2015. Response of plant functional traits during the restoration of calcareous grasslands from forest stands. Ecol. Indic., 48, 408-416, doi. org/10.1016/j.ecolind.2014.08.039

Piqueray J. et al., 2019. Management of grassland-like wildflower strips sown on nutrient-rich arable soils: the role of grass density and mowing regime. Environ. Manage., 63(5), 647-657, doi.org/10.1007/s00267-01901153-y

R Core Team, 2018. $R$ : A language and environment for statistical computing - version 3.5.1.

Roberts H.A. \& Boddrell J.E., 1984. Seed survival and seasonal emergence of seedlings of some ruderal plants. J. Appl. Ecol., 21(2), 617, doi.org/10.2307/2403433

Smith H. et al., 2010. Short-term successional change does not predict long-term conservation value of managed arable field margins. Biol. Conserv., 143(3), 813-822, doi.org/10.1016/j.biocon.2009.12.025

Schmidt A., Kirmer A., Kiehl K. \& Tischew S., 2020. Seed mixture strongly affects species-richness and quality of perennial flower strips on fertile soil. Basic Appl. Ecol., 42, 62-72, doi.org/10.1016/j.baae.2019.11.005

Stoate C. et al., 2001. Ecological impacts of arable intensification in Europe. J. Environ. Manage., 63(4), 337-365, doi.org/10.1006/jema.2001.0473

Uyttenbroeck R. et al., 2015. Creating perennial flower strips: think functional! Agric. Agric. Sci. Procedia, 6, 95-101, doi.org/10.1016/j.aaspro.2015.08.044

Uyttenbroeck R. et al., 2016. Pros and cons of flowers strips for farmers: a review. Biotechnol. Agron. Soc. Environ., 20, 225-235.

Uyttenbroeck R. et al., 2017. Increasing plant functional diversity is not the key for supporting pollinators in wildflower strips. Agric. Ecosyst. Environ., 249, 144155 .

Westbury D.B. et al., 2017. Buffer strip management to deliver plant and invertebrate resources for farmland birds in agricultural landscapes. Agric . Ecosyst. Environ., 240, 215-223.

(19 ref.) 


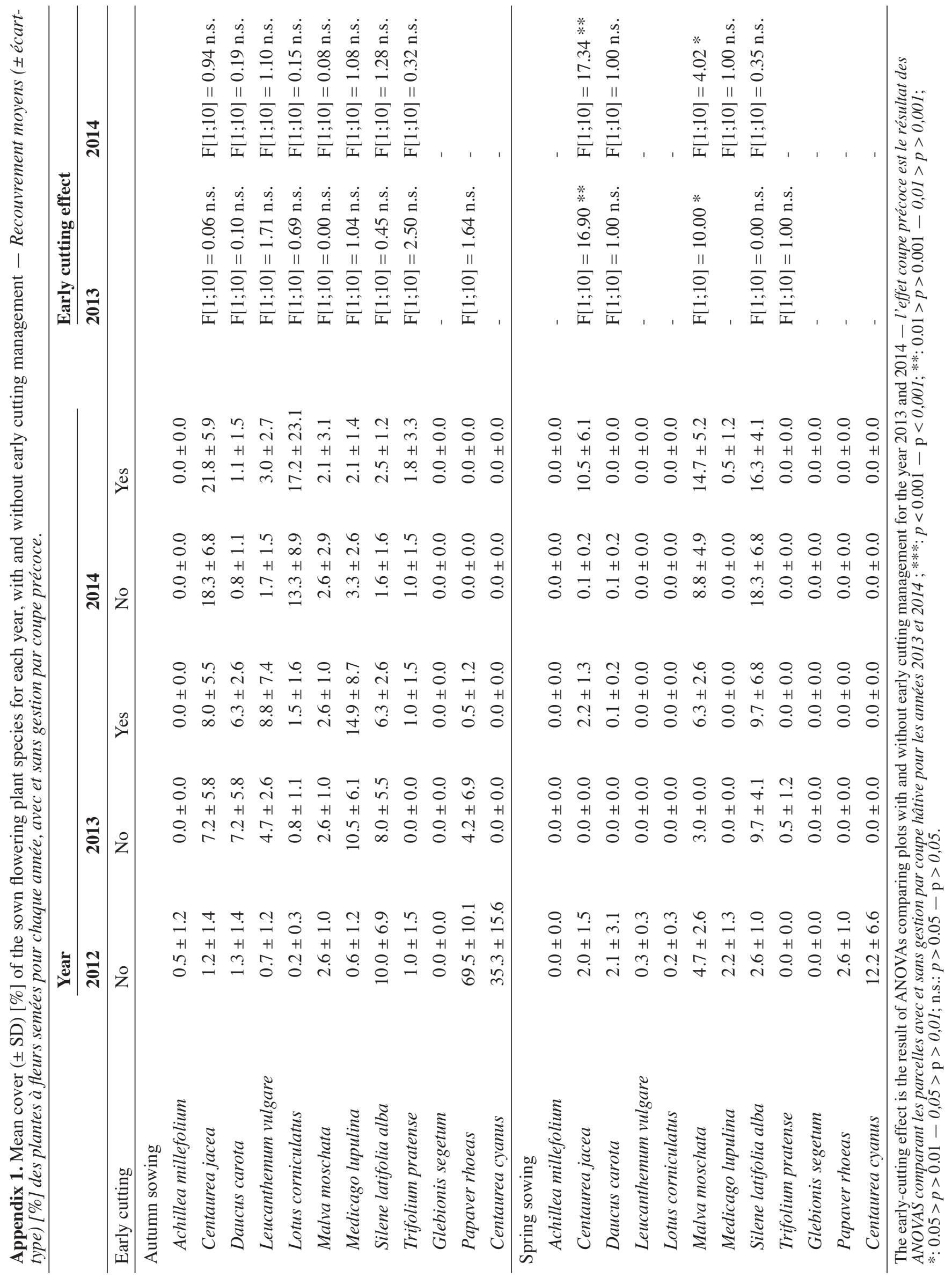

